\title{
Microbial functional diversity and enzymatic activity of soil degraded by sulphur mining reclaimed with various waste**
}

\author{
Jolanta Joniec ${ }^{1}$ and Magdalena Frac ${ }^{2}$ \\ ${ }^{1}$ Faculty of Agrobioengineering, Department of Environmental Microbiology, University of Life Sciences in Lublin, \\ Leszczyńskiego 7, 20-069 Lublin, Poland \\ ${ }^{2}$ Institute of Agrophysics, Polish Academy of Sciences, Doświadczalna 4, 20-290 Lublin, Poland
}

Received March 11, 2017; accepted August 9, 2017

\begin{abstract}
The aim of the study was to evaluate microbial functional diversity based on community level physiological profiling and $\beta$-glucosidase activity changes in soil degraded by sulphur mining and subjected to reclamation with various waste. The experiment was set up in the area of the former 'Jeziórko' Sulphur Mine (Poland), on a soilless substrate with a particle size distribution of slightly loamy sand. The experimental variants included the application of post-flotation lime, sewage sludge and mineral wool. The analyses of soil samples included the assessment of the following microbiological indices: $\beta$-glucosidase activity and functional diversity average well color development and richness). The results indicate that sewage sludge did not exert a significant impact on the functional diversity of microorganisms present in the reclaimed soil. In turn, the application of other types of waste contributed to a significant increase in the parameters of total metabolic activity and functional diversity of the reclaimed soil. However, the temporal analysis of the metabolic profile of soil microorganisms demonstrated that a single application of waste did not yield a durable, stable metabolic profile in the reclaimed soil. Still, there was an increase in $\beta$-glucosidase activity, especially in objects treated with sewage sludge.

Keywords: functional diversity, $\beta$-glucosidase activity, degraded soil, recultivation, waste
\end{abstract}

\section{INTRODUCTION}

One of the methods for evaluating the effectiveness of reclamation treatments applied to degraded soil is monitoring its biological activity. As indicated by Cavigelli and Robertson (2000), the qualitative and quantitative composition of soil microbiocenoses plays a very important role in the course of many biological processes, and changes

\footnotetext{
*Corresponding author e-mail: jolanta.joniec@up.lublin.pl

**This work was financially supported by University of Life Sciences in Lublin. The Biolog analyses were performed using equipment bought with European Union funds, The Eastern Poland Development Programme 2007-2013, and Regional Laboratory of Renewable Energy, IA PAS Grant No. POPW.01.03.00-06-005/09.
}

therein influence the normal function of ecosystems. Soil microorganisms serve an essential function in the carbon and nutrient cycles; therefore, their enzymatic activity has an impact on soil fertility (Nannipieri et al., 2002).

Parameters that are widely used in the assessment of the soil environment status are represented by community level physiological profiles (CLPP) and enzymatic activity. As suggested by Campbell et al. (1997), the differences in the utilisation of substrates between culture conditions and the analysed soil may result in differences in the intensity of microbial activity in these dissimilar environments. Furthermore, Ros et al. (2008) argue that Biolog CLPPs do not reflect the functional capacities of the entire soil microbial community, but only reflect the capacities of a very limited subset of microbial genera. It is therefore recommended that the CLPP technique should be combined with other research techniques, e.g. the assessment of enzymatic activity.

Literature review reveals that, despite its shortcomings, the functional diversity of microbial communities is widely employed in investigating the effect of various types of anthropopressure on the soil environment. Floch et al. (2011) used functional diversity and enzymatic activity for assessing soil contamination with pesticides. The authors found that $\beta$-glucosidase activity is more sensitive than functional diversity as an indicator of soil resistance to pesticide contamination. Islam et al. (2011) used CLPP and the activity of $\beta$-glucosidase for evaluating the condition of soils fertilised with mineral fertilisers and compost. Some authors have demonstrated the effectiveness of the CLPP method in assessing the impact of sewage

(C) 2017 Institute of Agrophysics, Polish Academy of Sciences 
sludge on the soil environment (Oszust et al., 2015; Ros et al., 2006a; Suhadolc et al., 2010). Enzymatic activity is widely employed in monitoring ecological soil conditions, including degraded soils. Soil $\beta$-glucosidase activity is considered a good indicator of the effectiveness of recultivation processes (Cele and Maboeta, 2016; Doni et al., 2012; Ros et al., 2003; and Tejada et al., 2006).

The aim of the study was to evaluate microbial functional diversity and $\beta$-glucosidase activity changes in soil degraded by sulphur mining and subjected to reclamation utilising various types of waste. The present research was undertaken to address the problem of soil degradation and the importance of recycling waste for environmental protection.

\section{MATERIALS AND METHODS}

The study was modelled upon a field remediation experiment established by the Institute of Soil Science and Environmental Engineering, the University of Life Sciences in Lublin, Poland. The experiment was set up in the area of the former 'Jeziórko' Sulphur Mine (Poland, Podkarpacie Region, N50³3'09”, E21 ${ }^{\circ} 46^{\prime} 40^{\prime \prime}$ ), on a soilless formation with the particle size distribution of weakly loamy sand, strongly acidified, with poor sorptive properties and a low content of $\mathrm{C}_{\text {org }}$ and $\mathrm{N}_{\text {total }}$ (Table 1). Sulphur mining at the Mine was conducted with the Frasch method. The plots were established in three replications. The size of each plots was about $30 \mathrm{~m}^{2}$. In the particular variants, once at the beginning of the experiment, various remediation materials were applied to the soilless formation: flotation lime and NPK (80; 40; $\left.60 \mathrm{~kg} \mathrm{ha}^{-1}\right)$, (PFL+NPK); lime and sewage sludge (PFL $+\mathrm{SS}$ ); sewage sludge (SS); mineral

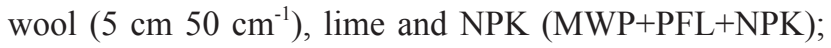

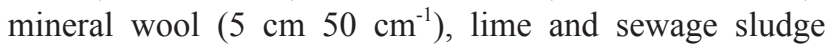
(MWP+PFL+SS); mineral wool $\left(500 \mathrm{~m}^{3} \mathrm{ha}^{-1}\right)$, lime and
NPK (MW+PFL+NPK); mineral wool $\left(500 \mathrm{~m}^{3} \mathrm{ha}^{-1}\right)$, lime and sewage sludge (MW+PFL+SS). Lime (PFL) was applied at a dose of $100 \mathrm{tha}^{-1}$, sewage sludge was distributed within the soil layer of $20 \mathrm{~cm}$ in the amount of $100 \mathrm{t}$ $\mathrm{ha}^{-1}$. Mineral wool was applied in two variants, i.e. in the form of a $5 \mathrm{~cm}$ insert at the depth of $50 \mathrm{~cm}$ (MWP), and at a dose of $500 \mathrm{~m}^{3} \mathrm{ha}^{-1}$, distributed within the layer of 0-20 cm (MW). Plots prepared in that manner were sown with a mix of grasses. The control treatment in the experiment was an unchanged plot (UNP).

The experiment included the following objects:

- (UNP) ground without changes, control

- (PFL) lime + NPK

- (PFL+ SS) lime + sewage sludge

- (SS) sewage sludge

- (MWP + PFL) wool $5 \mathrm{~cm} 50 \mathrm{~cm}^{-1}+$ lime + NPK

$-(\mathrm{MWP}+\mathrm{PFL}+\mathrm{SS})$ wool $5 \mathrm{~cm} 50 \mathrm{~cm}^{-1}+$ lime + sewage sludge

$-(\mathrm{MW}+\mathrm{PFL})$ wool $500 \mathrm{~m}^{3} \mathrm{ha}^{-1}+$ lime + NPK

$-(\mathrm{MW}+\mathrm{PFL}+\mathrm{SS})$ wool $500 \mathrm{~m}^{3} \mathrm{ha}^{-1}+$ lime + sewage sludge.

Prior to the analyses, the particle size distribution and reaction, sorptive capacity, content of $\mathrm{C}_{\text {org }}$ and $\mathrm{N}_{\text {total }}$ were determined in the degraded ground and in the waste materials used for the remediation. The assays were conducted at the Institute of Soil Science and Environmental Engineering, the University of Life Sciences in Lublin. The results are presented in Table 1.

Soil samples from the remediation experiment were collected from the layer of $0-20 \mathrm{~cm}$, twice during the $1 \mathrm{st}$ year of the experiment (in spring - on 6 May 2011 and summer - on 1 July 2011) and once in the 2nd and 3rd year of the experiment (in summer - on 22 June 2012 and 20 July 2013). Soil samples were collected in three replications, then transported and stored in plastic containers at $4^{\circ} \mathrm{C}$ before analysis.

Table 1. Selected properties of the degraded ground and the wastes used for remediation (Joniec et al., 2015)

\begin{tabular}{|c|c|c|c|c|c|}
\hline Properties & Unit & $\begin{array}{l}\text { Degraded } \\
\text { ground }\end{array}$ & $\begin{array}{c}\text { Mineral } \\
\text { wool }\end{array}$ & $\begin{array}{l}\text { Sewage } \\
\text { sludge }\end{array}$ & $\begin{array}{l}\text { Flotation } \\
\text { lime }\end{array}$ \\
\hline \multirow{3}{*}{$\begin{array}{l}\text { Particle size } \\
\text { distribution }\end{array}$} & $\%$ sand & 91 & & & 35 \\
\hline & $\%$ silt & 3 & n.t. & n.t. & 29 \\
\hline & $\%$ fine fract. & 6 & & & 36 \\
\hline $\mathrm{pH}$ & $1 \mathrm{~mol} \mathrm{KCl}$ & 4.3 & $5.3-6.6$ & 6.4 & 6.8 \\
\hline $\mathrm{T}$ & $\operatorname{cmol}(+) \mathrm{kg}^{-1}$ & 7.0 & 60.9 & 54.5 & 122.9 \\
\hline $\mathrm{N}_{\text {total }}$ & $\mathrm{g} \mathrm{kg}^{-1}$ & 0.3 & 5.3 & 28.0 & 10.4 \\
\hline $\mathrm{C}_{\text {org }}$ & & 2.0 & 28.5 & 193.8 & 2.58 \\
\hline $\begin{array}{l}\beta \text {-glucosidase } \\
\text { activity }\end{array}$ & $\begin{array}{l}\text { mg PNP kg-1 d.m. } \\
\quad \text { soil h}^{-1}\end{array}$ & n.t. & 0.80 & 99.18 & 1.20 \\
\hline
\end{tabular}

n.t. - not tested, T - sorptive capacity. 
The functional diversity (catabolic potential) was assessed using such indices as average well color development (AWCD) and richness (R). These indices were calculated following the community level physiological profiling (CLPP) using Biolog Eco Plates with a set of carbon sources proposed by Insam (1997). The percentage of carbon substrates groups including carbohydrates, amino acids, amines and amides, carboxylic acids and polymers was also calculated based on absorbance measurements. Each well of the Biolog EcoPlate ${ }^{\circledR}$ was inoculated with $120 \mu \mathrm{l}$ of inoculum and incubated at $27^{\circ} \mathrm{C}$. Absorbance was read every $24 \mathrm{~h}$ during $216 \mathrm{~h}$ of incubation for each soil sample at $590 \mathrm{~nm}$ using Biolog MicroStation ${ }^{\mathrm{TM}}$.

$\beta$-glucosidase activity was determined according to Eivazi and Tabatabai (1998), with p-nitrophenyl- $\beta$-Dglucoside (PNPG) as a substrate.

AWCD, richness $(R)$ indices and $\beta$-glucosidase actiity were compiled on the basis of the analysis of variance (ANOVA). ANOVA was used to evaluate the changes in soil microbial properties among the different reclamation approaches. Cluster analysis was used to evaluate the substrates which were the most utilised in each soil sample. The percentage of guild groups was assessed to determine the most intensively utilised carbon source groups in particular objects. The data were standardised by the average well colour development in each microplate to remove inoculum density effects. All statistical analyses were performed with the Statistica software, version 12.

\section{RESULTS}

Data presented in Fig. 1a and Fig. 2a show that the waste applied to the degraded soil had a significant effect on the total soil metabolic activity (AWCD index) and its func-

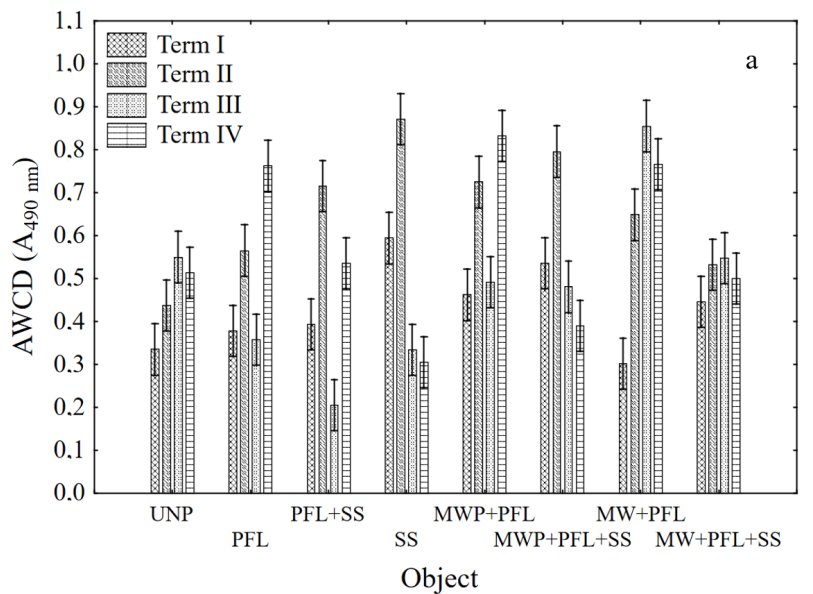

tional diversity ( $\mathrm{R}$ index). The values of the AWCD and $\mathrm{R}$ (richness) indices have shown certain dynamics of changes depending on the term of the analysis and the type of the applied waste (Fig. 1a and Fig. 2a). In term I, the parameters in some objects treated with sewage sludge MWP+PFL+SS and mineral wool MWP+PFL had significantly higher values than those in UNP. An analogical effect was also found in term IV in objects without the addition of sewage sludge, i.e. PFL, MWP+PFL, and MW+PFL. In the final stage of the experiment, there was a decline in the AWCD and $\mathrm{R}$ values induced by the application of sewage sludge (SS). In term II, higher values of the AWCD and R indices were noted in almost all objects reclaimed with waste (with the exception of MW+PFL+SS), as compared with UNP. Importantly, the analysis of the changes in these parameters in term III revealed a significant decrease in the AWCD and $\mathrm{R}$ values or the absence of significant differences in a majority of the waste-treated objects as compared with UNP. Notable is the fact that application of sewage sludge increased the AWCD and R values (SS, MWP+PFL+SS) in the initial period. However, the positive impact of this type of waste declined (MWP+PFL+SS) with time or even changed into a negative effect (SS). In turn, the positive effect of mineral wool applied in combination with postfloatation lime (MWP+PFL, MW+PFL) generally persisted throughout the investigation period. The application of sewage sludge in combination with post-floatation lime and mineral wool mixed with soil (MW+PFL+SS) into the degraded substrate did not have a significant effect on the magnitude of the analysed parameters in any of the terms. Therefore, the mean values of the AWCD and R indices from three years (Fig. 1b and Fig. 2b) indicate that only

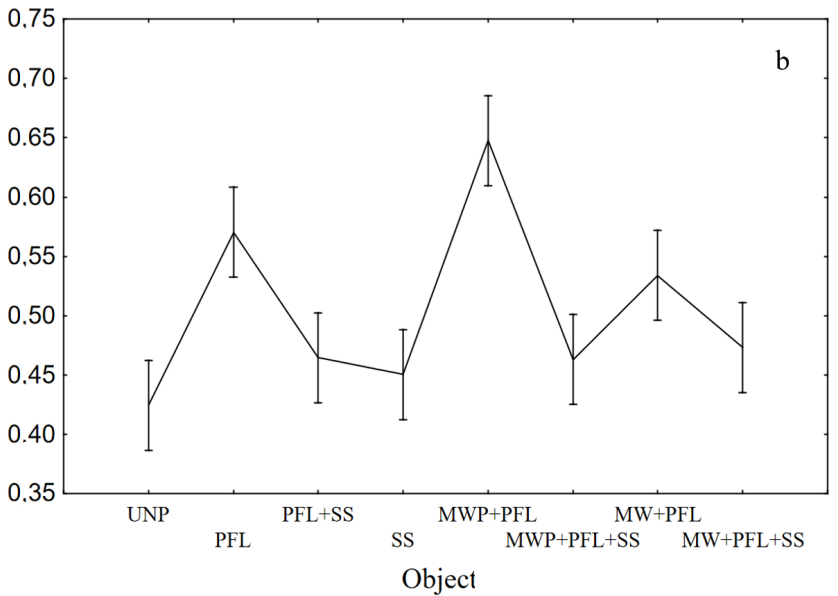

Fig. 1. Average well color development (AWCD) values based on the CLPP analysis in reclaimed soil. Explanations: a - variations in different terms of analyses; $b$ - mean values for particular objects, from terms I-IV. UNP - ground without changes, control; PFL lime + NPK $\left(80,40,60 \mathrm{~kg} \mathrm{ha}^{-1}\right) ; \mathrm{PFL}+\mathrm{SS}-$ lime + sewage sludge $100 \mathrm{t} \mathrm{ha}^{-1} ; \mathrm{SS}-$ sewage sludge $100 \mathrm{tha}{ }^{-1} ; \mathrm{MWP}+\mathrm{PFL}-\mathrm{wool} 5 \mathrm{~cm}$ $50 \mathrm{~cm}^{-1}+$ lime + NPK $\left(80,40,60 \mathrm{~kg} \mathrm{ha}^{-1}\right) ; \mathrm{MWP}+\mathrm{PFL}+\mathrm{SS}-$ wool $5 \mathrm{~cm} 50 \mathrm{~cm}^{-1}+$ lime + sewage sludge $100 \mathrm{tha}{ }^{-1} ; \mathrm{MW}+\mathrm{PFL}-\mathrm{wool}$ $500 \mathrm{~m}^{3} \mathrm{ha}^{-1}+$ lime + NPK $\left(80,40,60 \mathrm{~kg} \mathrm{ha}^{-1}\right) ; \mathrm{MW}+\mathrm{PFL}+\mathrm{SS}-$ wool $500 \mathrm{~m}^{3} \mathrm{ha}^{-1}+$ lime + sewage sludge $100 \mathrm{t}^{-1}$. Vertical bars denote 0.95 confidence intervals. Term I - spring 2011/1st year, term II - summer 2011/1st year; term III - summer 2012/2nd year; term IV - summer 2013/3rd year. 

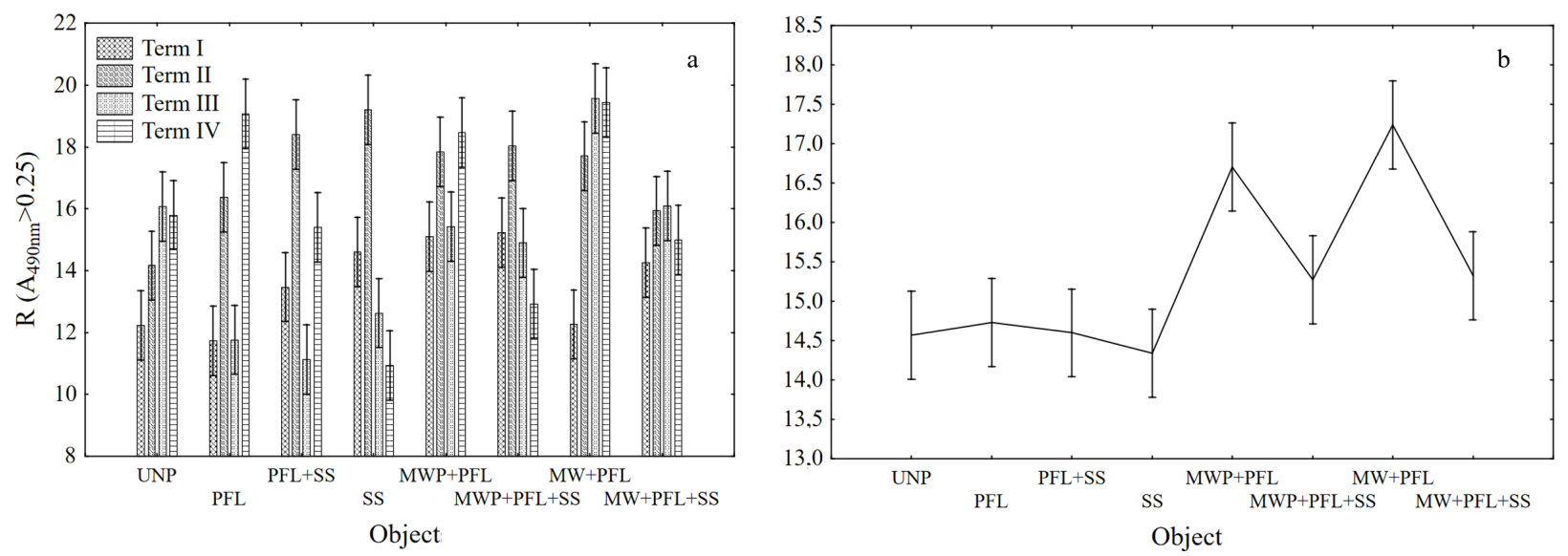

Fig. 2. Richness (R) values based on the CLPP analysis in reclaimed soil. Explanations as in Fig. 1.

post-floatation lime (PFL) and mineral wool applied for reclamation in two modes (MWP+PFL, MW+PFL) had a positive effect.

The data presented in Fig. 3 indicate that the number of metabolised substrates (R) increased along the incubation time. In all objects, a distinct rise in the $\mathrm{R}$ index was noted after 48 hours. However, the number of utilised substrates was the highest in soil reclaimed with post-floatation lime in combination with mineral wool, as applied in two modes $(\mathrm{MWP}+\mathrm{PFL}, \mathrm{MW}+\mathrm{PFL})$. The value of this parameter in the other waste-treated objects was lower and similar to UNP.

The analysis of the results of the metabolic profile of the substrate groups (Fig. 4) revealed certain differences in some objects in comparison with UNP. Such differences depended on the type of waste applied and the duration of their impact on the soil environment. In the initial period of the experiment, the waste-treated object, in comparison with UNP, exhibited generally lower levels of utilisation of amines and amides, as well as higher rates of catabo-

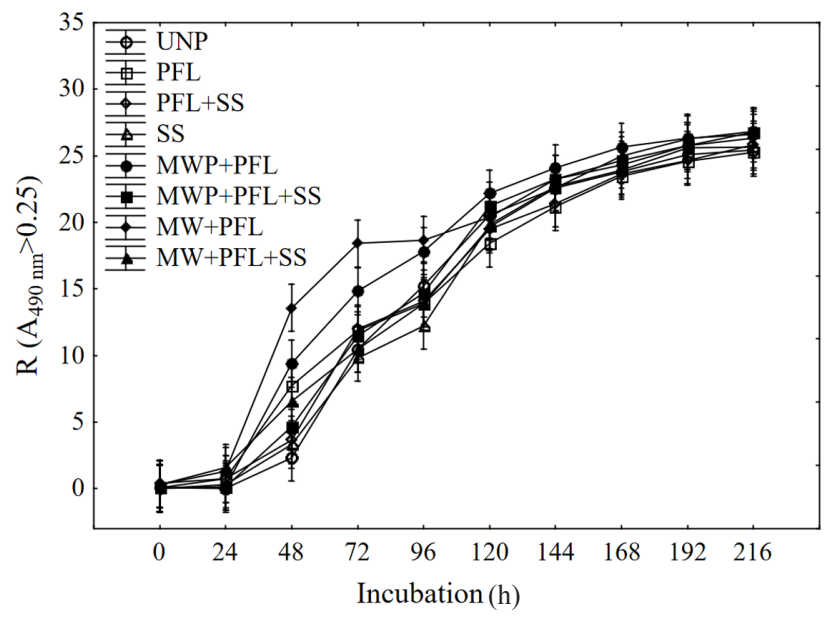

Fig. 3. Richness $(\mathrm{R})$ values of metabolised substrates in Biolog EcoPlates based on 216-h incubation $(n=3)$. Explanations as in Fig. 1. lism of amino acids, carboxylic acids. In turn, after 3 years, the metabolic profile of the substrate groups in the wastetreated objects exhibited a higher percentage of utilisation of amines and amides and a lower percentage of carbohydrates. Furthermore, the results have shown that amino acids were generally the most intensively metabolised group of substrates in both terms. Figure 5 presents the results concerning the groups of the objects and characteristics of the ability of microorganisms in the analysed combinations to metabolise single substrates from a given category of compounds. The results indicate that pyruvic acid methyl ester (C1) representing carbohydrates and L-serine (C27) from the amino acids group were the most intensively and most frequently utilised $\mathrm{C}$ sources in the initial and final periods of the study. In addition, certain dynamics of changes depending on the duration of the experiment was noted. In the initial period, another amino acid, L-arginine (C24), and the carbohydrate, D-xylose (C9), as well as the polymer, Tween $40(\mathrm{C} 2)$, were also intensively catabolised in

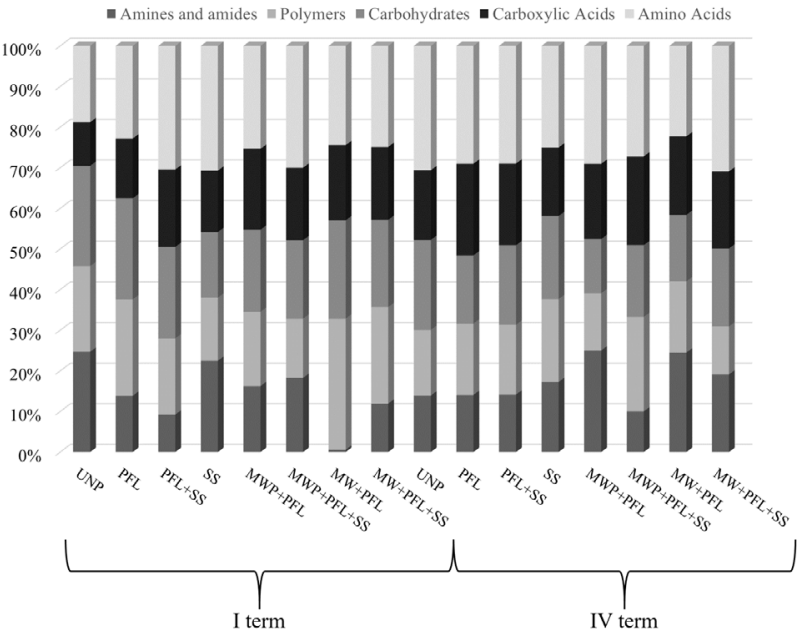

Fig. 4. Percentage of total carbon source utilisation response for particular objects of reclaimed soil in different stages of the experiment. Explanations as in Fig. 1. 


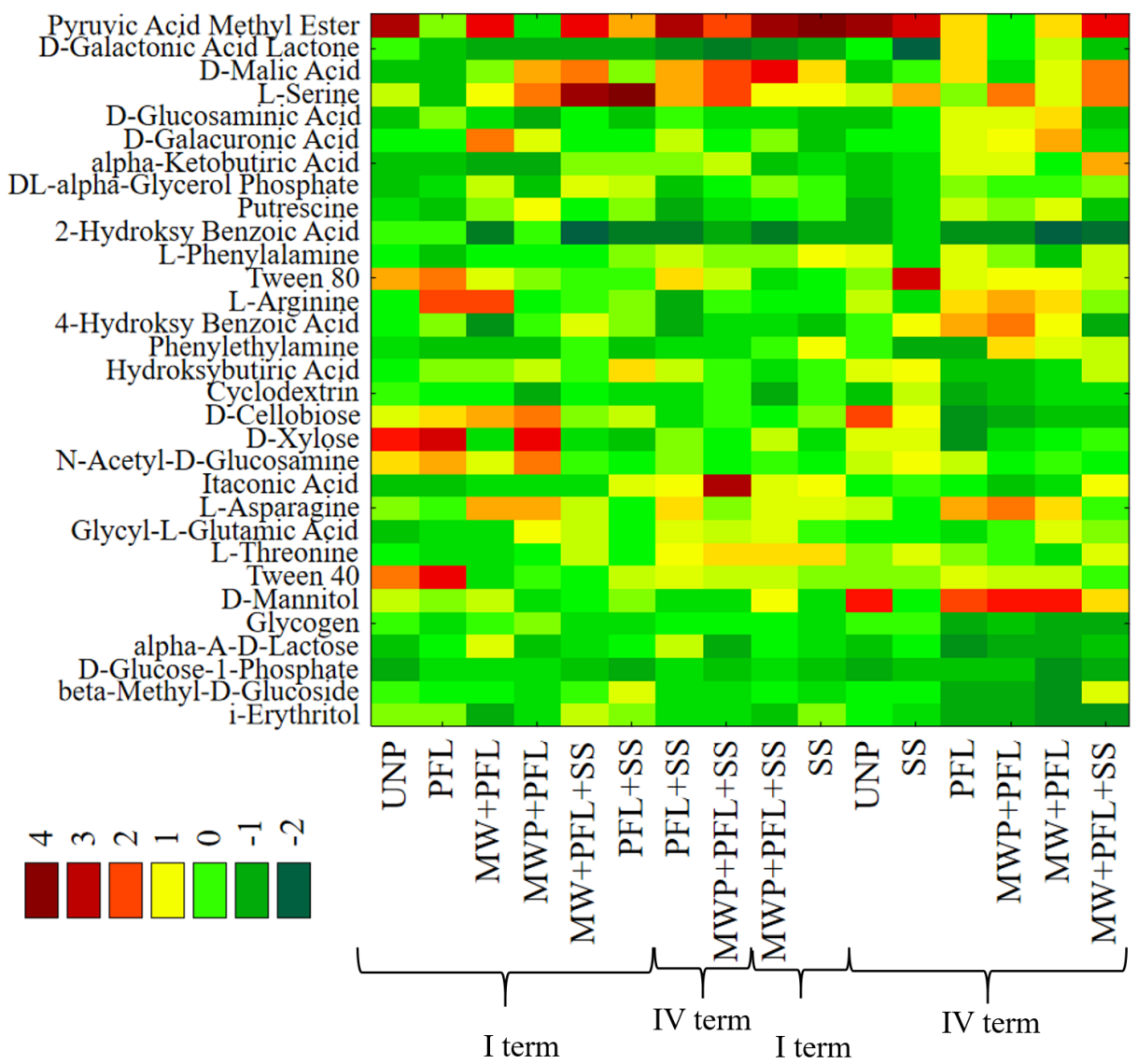

Fig. 5. Heat map based on Biolog EcoPlateTM carbon sources utilisation patterns by the microbial communities from reclaimed soil. Explanations as in Fig. 1.

some objects. In turn, it was observed after 3 years that, additionally, the carbohydrate, D-mannitol (C11), and another carbohydrate, D-cellobiose (C6), as well as the polymer, Tween $80(\mathrm{C} 3)$, in some objects, were utilised most intensively. The analysis of the object grouping and characteristics has revealed that 6 carbohydrates and amino acids and 2 polymers were the most important of all the 31 carbon sources analysed in the metabolism of microorganisms inhabiting the objects.

Figure 6 shows the results of cluster analysis of the experimental objects based on their metabolic profile. The results indicate that they can be divided into 3 groups according to the ability of the microorganisms present in the individual objects in each term to catabolise the 31 different carbon substrates. The microbial catabolic abilities were characterised by certain dynamics of changes depending on the type of the waste applied for reclamation and the duration of its action. The first group included all the wastetreated objects from term II of the study and the non-treated objects from term IV $(26,29,31)$. The second group, which was the least numerous, comprised objects from terms I and IV reclaimed with the application of sewage sludge (3, $4,6,8)$. The third group included objects from term I that were not treated with sewage sludge and objects from term
III (with the exception of 23, 24). Furthermore, the control soil and soil enriched only with sewage sludge from the final stage of the experiment exhibited a similar metabolic profile $(25,4)$. The results presented in Fig. 7 indicate that the waste applied to the degraded soil induced changes in the activity of $\beta$-glucosidase. As in the case of the metabolic parameters, the changes depended on the type of the waste and the duration of their action in the soil environment (Fig. 7). In the first year of the experiment (i.e. terms I and II), the application of the waste resulted in an increase in $\beta$-glucosidase activity in a majority of the objects (combinations PFL, PFL+SS, SS, MW+PFL, MW+PFL+SS). The application of a $5 \mathrm{~cm} 50 \mathrm{~cm}^{-1}$ mineral wool pad $(\mathrm{MWP}+\mathrm{PFL}, \mathrm{MWP}+\mathrm{PFL}+\mathrm{SS})$ for soil reclamation was the only unfavourable treatment, as it led to a decline in this parameter. The negative effect of the applied waste was enhanced with time. In terms III and IV, the effect was visible in nearly all the objects. The positive effect persisted only in the sewage sludge-treated objects (combinations $\mathrm{PFL}+\mathrm{SS}, \mathrm{SS}, \mathrm{MW}+\mathrm{PFL}+\mathrm{SS}$ ). The results of the analysis of the mean values from the entire 3-year study period collected for the individual objects (Fig. 7b) showed that sewage sludge applied separately (SS) or in combination with the other waste $(\mathrm{PFL}+\mathrm{SS}, \mathrm{MW}+\mathrm{PFL}+\mathrm{SS})$ had a stimulatory 


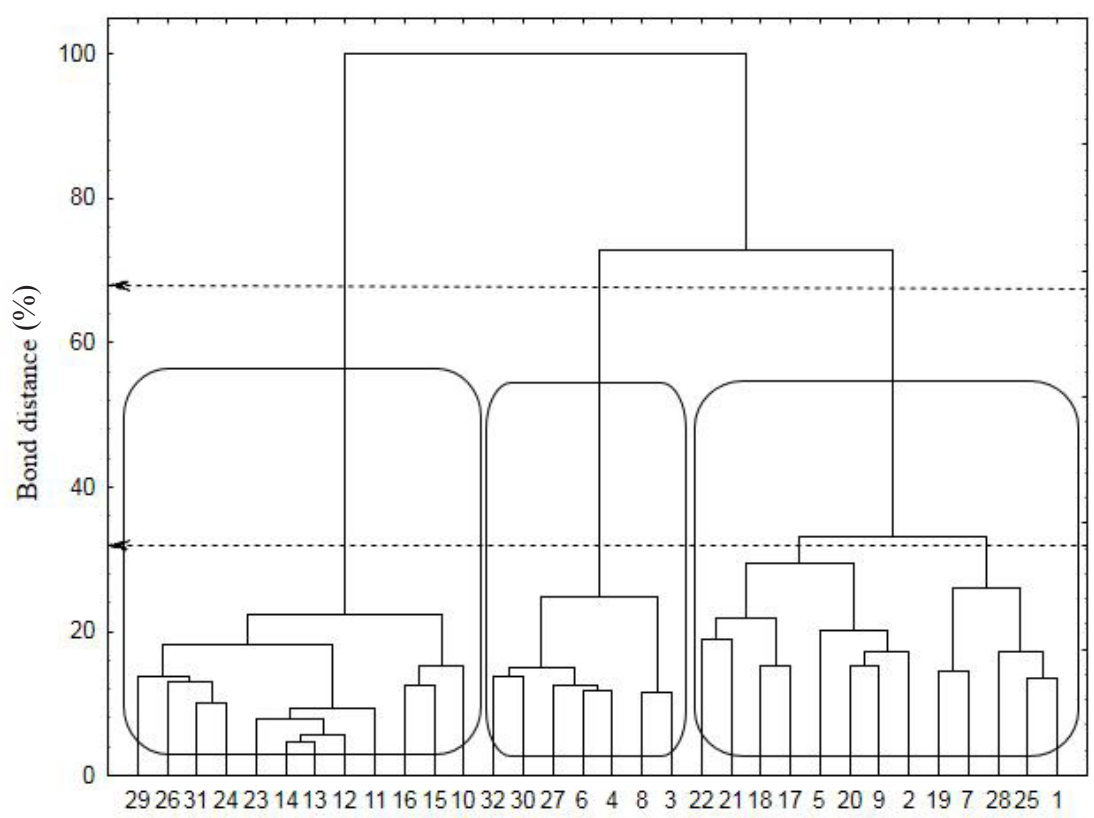

Fig. 6. Dendrogram of the bond distances between the carbon utilisations patterns of the substrates located on the Biolog EcoPlates ${ }^{\mathrm{TM}}$. Grouping was conducted according to the stringent Sneath criterion (33\%) and the less restrictive criterion (66\%), respectively. Terms of analyses: I: 1-8, II: 9-16, III: 17-24, IV: 25-32; UNP - 1, 9, 7, 25; PFL - 2, 10, 18, 26; PFL+ SS - 3, 11, 19, 27; SS - 4, 12, 20, 28; $\mathrm{MWP}+\mathrm{PFL}-5,13,21,29 ; \mathrm{MWP}+\mathrm{PFL}+\mathrm{SS}-6,14,22,30 ; \mathrm{MW}+\mathrm{PFL}-7,15,23,31 ; \mathrm{MW}+\mathrm{PFL}+\mathrm{SS}-8,16,24,32$. Explanations as in Fig. 1.
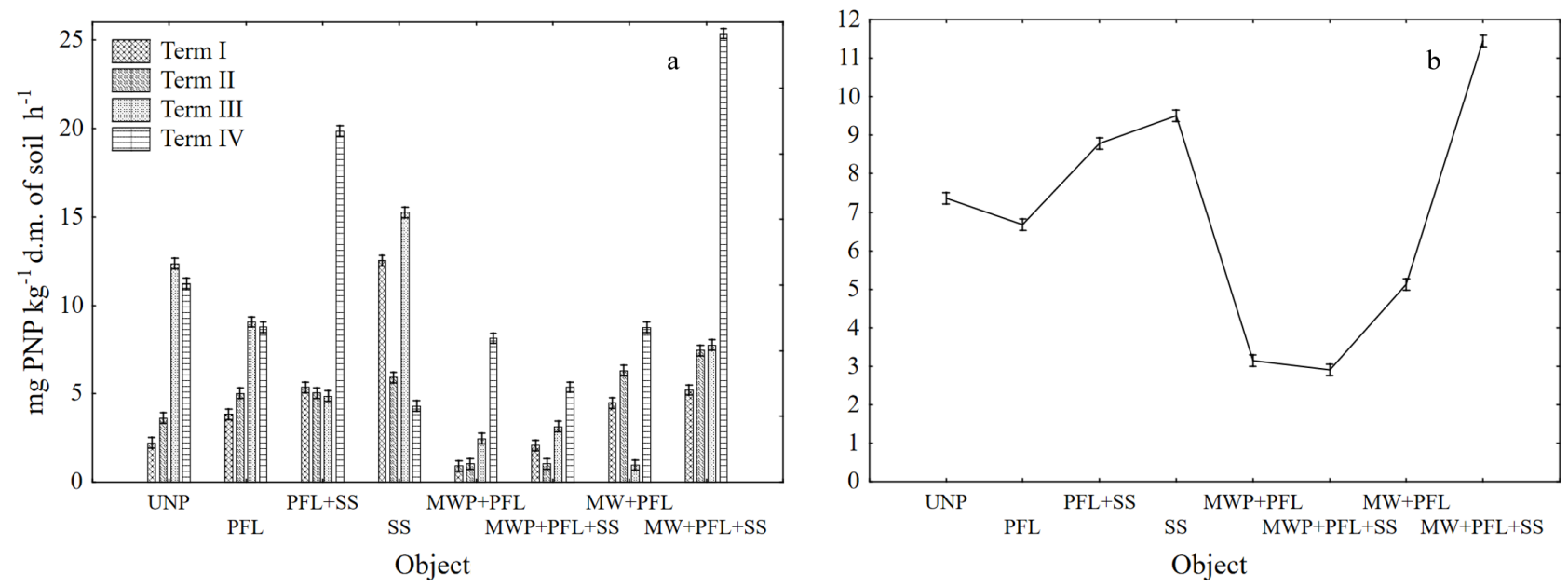

Fig. 7. $\beta$-glucosidase activity in particular objects of reclaimed soil in different terms of the experiment (a); mean values of $\beta$-glucosidase activity in particular objects of reclaimed soil (b). Explanations as in Fig. 1.

effect on $\beta$-glucosidase activity. The highest stimulation of this parameter was noted upon the application of seage sludge with post-floatation lime and wool mixed with soil at the dose of $500 \mathrm{~m}^{3} \mathrm{ha}^{-1}(\mathrm{MW}+\mathrm{PFL}+\mathrm{SS})$. In the other objects, i.e. MWP+PFL and MWP+PFL+SS, the activity of this enzyme was reduced.

\section{DISCUSSION}

The analysis indicated that the effect of sewage sludge on the AWCD and R indices of the metabolic profile noted in the individual study terms was initially positive, but declined with time or changed into a negative impact in term III (PFL+SS, SS). This was probably a result of the introduction of organic matter as a source of microbial nutrients and microorganisms with varied catabolic capacities, into the sewage sludge-treated degraded soil. Furthermore, the particularly strong and beneficial effect of sewage sludge on the biological status of the soil environment is associated with the great positive impact of the waste on the content of organic matter and nutrients, soil porosity, bulk density, aggregate structure, water capacity, water repellence and hydraulic conductivity of soil aggregates (Singh 
and Agrawal, 2008; Król et al., 2015). Probably, the general living conditions for the microorganisms have improved in the present experiment. A similar increase in the soil catabolic potential induced by sewage sludge was also reported by Frąc et al. (2014), Ros et al. (2006a), and Suhadolc et al. (2010). Furthermore, the increase in the soil catabolic potential in the sewage sludge-treated objects may have been caused by sedimentary microorganisms (Frąc et al., 2014). The negative effect of sewage sludge, which was increasingly pronounced with time, may have been connected with the depletion of organic matter, which is known to mask the negative effect of xenobiotics on soil microorganisms (Franco-Otero et al., 2012; Moreno et al., 2002). The values of the AWCD and R indices obtained in the different terms revealed that the effect of the other waste, i.e. postfloatation lime and mineral wool, on the metabolic profile of the reclaimed soil was more distinct than the effect of sewage sludge. In the case of post-floatation lime added in combination with the mineral wool pad, or with mineral wool, and mixed with soil (MWP+PFL, MW+PFL), the stimulatory effect of these waste persisted throughout the investigation period. The increase in the analysed indicators in the objects treated with post-floatation lime and wool and containing small amounts of nutrients may have been caused by adaptation of the microorganisms to the culture conditions, which were rich in substrates. As suggested by Campbell et al. (1997), the differences in the content of the substrates between the culture conditions and the analysed soil may result in different microbial activities in these dissimilar environments. Investigations conducted by other authors (Fierer et al., 2007; Hattori and Hattori, 1980; Joniec et al., 2015) have shown that microorganisms with low nutritional requirements proliferate intensively in a nutrient-rich environment. These observations have been confirmed by the results of the number of metabolised substrates reported in the present study (Fig. 4), which was noted to increase in the post-floatation lime- and wool-treated objects (MWP+PFL, MW+PFL) with the incubation time.

The results of other authors have shown that sewage sludge, mineral wool and post-flotation lime applied together in different variants had a positive influence on the physical, chemical and biological properties of the soil degraded by the "Jeziórko" Sulphur Mine (Baran et al., 2011; Joniec, 2013; Joniec et al., 2015). Baran et al. (2011) have reported improvements of the following parameters: humidity, density, $\mathrm{pH}$, sorption capacity, carbon content, nitrogen and available forms of potassium, phosphorus and magnesium. Joniec (2013) and Joniec et al. (2015) recorded the stimulation of biological life in reclaimed soil collected from the experimental model presented in this paper. The results indicated an increase in the number of different microorganisms groups and their biochemical and enzymatic activity, including respiratory activity, cellulose mineralisation, nitrification and lipase, protease, arylsulfase and alkaline phosphatase activity. These results indicate the high usefulness of applied waste in the reclamation of degraded land. Baran et al. (2011) emphasise that the use of mineral wool in various variants with sewage sludge and post-flotation lime for reclamation is pioneering. However, taking into account the amounts of these waste, the phenomenon of soil degradation and their wide positive impact on soils properties, it is justified to use these in various combinations for the reclamation of degraded soils on a larger scale.

As shown in the study conducted by Furczak and Joniec (2009), the positive effect of sewage sludge on selected enzymatic activities also declined over time. This implies that AWCD and R indicators, similar to enzymatic parameters, are useful in monitoring changes occurring in waste-reclaimed soil. The results presented in Figs 5 and 6 show that the analysed soil was characterised by a diverse utilisation of carbon substrates. The strong carbohydrate metabolic activity in both the control and reclaimed soils suggests the presence in the degraded soil of microorganisms that utilise this carbon source first. The assessment of the metabolic profile of the examined soil environment has revealed some differences in the carbohydrate metabolic activity depending on the type of waste applied. It was noted that the catabolism of this compound group was especially intense in the objects treated with sewage sludge for reclamation. The application of this type of waste to the soil activated microorganisms that were able to utilise amino acids as a carbon source, which are known to be a source of another important nutrient for microorganisms, i.e. nitrogen. This was induced by enriching the degraded soil with carbon and nitrogen organic matter (Table 1) and the introduction of microorganisms that are capable of using it as a source of nutrients. As in the study conducted by Joniec (2013) and Joniec et al. (2015), the sewage sludge applied in this experiment added a certain pool of these microorganisms into the soil environment. The results of the cluster analysis of the individual experimental objects (Fig. 6) revealed that the microbial metabolic profile in the control soil was the same throughout the experiment. In turn, it changed in the reclaimed objects depending on the duration of the impact of waste on the soil environment. These observations suggest that a single application of waste did not yield a durable, stable metabolic profile in the reclaimed soil.

The results presented in Fig. 7 showed that the enzymatic parameter analysed in the present study, i.e. $\beta$-glucosidase activity, also underwent changes induced by the waste applied for reclamation. The effect of the sewage sludge on this parameter was initially similar to that on the metabolic profile indices, i.e. AWCD and R. The increase in the activity noted in the initial period in objects treated with sewage sludge declined with time, but persisted in single objects in the last year of the study as well, unlike the AWCD and R indices. An increase of $\beta$-glucosidase activity 
in soil after 2 years of reclamation with sewage sludge was reported by Ros et al. (2003). In turn, the use of the mineral wool pad (MWP+PFL, MWP+PFL+SS) proved to have an adverse effect. The reduction of $\beta$-glucosidase activity in these objects was noted throughout the experimental period. The available literature shows that sewage sludge has a stimulatory effect on soil enzymatic activity (Bastida et al., 2008; Lakhard et al., 2010; Nicolas et al., 2012; Ros et al., 2006b). The increase in the $\beta$-glucosidase activity may have been caused by the supply of nutrients utilised by microorganisms, as well as microorganisms themselves, and certain enzymes contained in sewage sludge. The data presented in Table 1 and in the study by Joniec et al. (2015) demonstrate that waste used for reclamation, notably sewage sludge, are a potent source of nutrients and exhibit some microbiological and enzymatic activity. Furthermore, the results of the analysis of the content of $\mathrm{C}_{\text {org }}$ and $\mathrm{N}_{\text {total }}$ in the reclaimed soil have shown an increase in their level. This was induced by the addition of all waste types, with the strongest effect noted in the combinations with sewage sludge (data unpublished). This was reflected in the highest increase in these objects. Similar conclusions concerning the stimulatory effect of sewage sludge on soil enzymatic activity were reported by other authors (Bastida et al., 2008; Frąc and Jezierska-Tys, 2011; Lakhard et al., 2010; Marschner et al., 2003; Nicolas et al., 2012).

The increase in the $\beta$-glucosidase activity persisting in the third year of the study in single sewage sludge-treated objects may have been caused by the formation of complexes of the enzyme with soil colloids. As suggested by Burns et al. (2013), many exoenzymes become stabilised through association with clay minerals, humic acids and particulate organic matter, and retain significant levels of activity for prolonged periods. Doni et al. (2012) in investigating the enzymatic activity of degraded soils, found that the active humic- $\beta$-glucosidase enzyme complexes are relevant indicators for assessing the amount and role of humic carbon in degraded soils following regeneration practices.

\section{CONCLUSIONS}

1. Sewage sludge applied for reclamation did not alter significantly the functional diversity of the microorganisms present in the reclaimed soil. In turn, the application of other waste types, i.e. post-floatation lime and mineral wool, contributed to a significant increase in the indices of total metabolic activity and functional diversity of the reclaimed soil.

2. The decline in the effect of sewage sludge on the soil metabolic profile indices, i.e. average well color development and richness observed over time suggests that this waste did not contribute to durable favourable changes in the metabolic potential of the reclaimed soil.
3. The temporal analysis of the metabolic profile of soil microorganisms indicates that a single application of waste did not yield a durable, stable metabolic profile in the reclaimed soil.

4. Analysis of the mean values from the entire study period have shown that sewage sludge applied separately or in combination with other types of waste had a stimulatory effect on $\beta$-glucosidase activity. The application of the mineral wool pad resulted in a reduction of the activity of the enzyme.

5. The optimal composition of the remedial material improving the analysed microbiological parameters included a mixture of post-flotation lime and mineral wool. However, it is desirable to re-use these types of waste to maintain their positive impact on soil microorganisms. Furthermore, the use of sewage sludge is also advisable for maintaining a high microbial activity of reclaimed soil.

Conflict of interest: The Authors do not declare conflict of interest.

\section{REFERENCES}

Baran S., Hermann J., Żukowska G., and WójcikowskaKapusta A., 2011. Mineral wool in environmental shaping and protection. In: Environmental waste utilisation. Theoretical and practical basics (in Polish). (Eds S. Baran. J. Łabętowicz, E. Krzywy). PWRiL, Warsaw, Poland.

Bastida F., Kandeler E., Moreno J.L., Ros M., Garcia C., and Hernandez T., 2008. Application on fresh and composted organic wastes modifies structure, size and activity of soil microbial community under semiarid climate. Applied Soil Ecology, 40, 318-329.

Burns R.G., DeForest J.L., Marxsen J., Sinsabaugh R.L., Stromberger M.E., Wallenstein M.D., Weintraub M.N. and Zoppini A., 2013. Soil enzymes in a changing environment: Current knowledge and future directions. Soil Biol. Biochem., 58, 216-234.

Campbell C.D., Grayston S.J., and Hirst D.J., 1997. Use of rhizosphere carbon sources in sole carbon source tests to discriminate soil microbial communities. J. Microbiol. Methods, 30, 33-41.

Cavigelli M.A. and Robertson G.P., 2000. The functional significance of denitrifier community composition in a terrestrial ecosystem. Ecology, 81, 1402-1414.

Cele E.N. and Maboeta M., 2016. Response of soil enzyme activities to synergistic effects of biosolids and plants in iron ore mine soils. Int. J. Environ. Sci. Technol., 13, 2117-2126.

Doni S., Macci C., Masciandaro G., and Ceccanti B., 2012. IEF technique to study the $\beta$-glucosidase-humic complexes in organic and mineral amended soils. In: Soil enzymology in the recycling of organic wastes and environmental restoration (Eds C. Trasar-Cepeda, T. Hernandez, C. Garcia, C. Rad, S. Gonzalez-Carcedo). Springer-Verlag, Dordrecht, London, New York.

Eivazi F. and Tabatabai M.A., 1988. Glucosidases and galactosidases in soils. Soil Biol. Biochem., 20, 601-606. 
Fierer N., Bradford M.A., and Jackson B., 2007. Toward an ecological classification of soil bacteria. Ecology, 88, 1354-1364.

Floch C., Chevremont A.C., Joanico K., Capowiez Y., and Criquet S., 2011. Indicators of pesticide contamination:Soil enzyme compered to functional diversity of bacterial communities via Biolog ${ }^{\circledR}$ Ecoplates. European J. Soil Biology, 47, 256-263.

Franco-Otero V.G., Soler-Rovira P., Hernandez D., Lopez-deSa E., and Plaza C., 2012. Short-term effects of organic municipal wastes on wheat yield, microbial biomass, microbial activity, and chemical properties of soil. Biol. Fertil. Soils, 48, 205-216.

Frąc M. and Jezierska-Tys S., 2011. Agricultural utilisation of dairy sewage sludge: Its effect on enzymatic activity and microorganisms of the soil environment. African J. Microbiology Res., 5, 1755-1762.

Frąc M., Oszust K., Lipiec J., Jezierska-Tys S., and Nwaichi E.O., 2014. Soil microbial functional and fungal diversity as influenced by municipal sewage sludge accumulation. Int. J. Environ. Res. Public Health, 11, 8891-8908.

Furczak J. and Joniec J., 2009. Microbial populations and activity of biochemical processes related to carbon and nitrogen transformations in podzolic soil under willow culture, in fifth year from treatment with sewage sludge. Polish J. Environ. Studies, 18, 801-810.

Hattori R. and Hattori T., 1980. Sensitivity to salts and organic compounds of soil bacteria isolated on diluted media. The J. General Appl. Microbiol., 26, 1-14.

Insam H., 1997. A new set of substrates proposed for community characterization in environmental samples. In: Microbial Communities. Functional versus Structural Approach (Eds H. Insam, A. Rangger). Springer, Berlin/Heidelberg, Germany.

Islam M.R., Chauhan P.S., Kim Y., Kim M., and Sa T., 2011. Community level functional diversity and enzyme activities in paddy soils under diffrent long-term fertilizer management practices. Biol. Fertil. Soils, 47, 599-604.

Joniec J., 2013. Microbiological transformations of N, S and P in degraded soil subjected to one-year remediation with various wastes. Polish J. Soil Sci., 46, 61-75.

Joniec J., Fruczak J., and Kwiatkowska E., 2015. Application of biological indicators for estimation of remediation of soil degraded by sulphur industry. Ecological Chemistry Eng. S, 22, 269-283.

Król A., Lipiec J., and Frąc M., 2015. The effect of dairy sewage sludge amendment on repellency and hydraulic conductivity of soil aggregates from two depths of Eutric Cambisol. J. Plant Nutrition Soil Sci., 178, 270-277.

Lakhdar A., Scelza R., Scotti R., Rao M.A., Jedidi N., Gianfredo L., and Abdelly Ch., 2010. The effect of com- post and sewage sludge on soil biologic activities in salt affected soil. Revista de la Ciencia del Suelo y Nutrición Vegetal, 10, 40-47.

Marschner P., Kandeler E., and Marschner B., 2003. Structure and function of the soil microbial community in a long-term fertilizer experiment. Soil Biology Biochemistry, 35, 453-461.

Moreno J.L., Hernàndez T., Pérez A., and Garcia C., 2002. Toxicity of cadium to soil microbial activity: effect of sewage sludge addition to soil on the ecological dose. Applied Soil Ecol., 21, 149-158.

Nannipieri P., Kandeler E., and Ruggiero P., 2002. Enzyme activities and microbial and biochemical processes in soil. In: Enzymes in the environment (Eds R.G. Burns, R.P. Dick). Marcel Dekker, New York.

Nicolas C., Hernandez T., and Garcia C., 2012. Organic amendments as strategy to increase organic matter in particle-size fractions of a semi-arid soil. Applied Soil Ecology, 57, 50-58.

Oszust K., Frac M., and Lipiec J., 2015. Soil microbial functionality in response to dairy sewage sludge and mineral fertilisers application under winter rape, Int. J.Environ. Sci. Technol., 12, 3675-3684.

Ros M., Goberna M., Pascual J.A., Klammer S., and Insam H., 2008. $16 \mathrm{~S}$ rDNA analysis reveals low microbial diversity in community level physiological profile assays. J. Microbiol. Methods, 72, 221-226.

Ros M., Hernandez M.T., and Garcia C., 2003. Bioremediation of soil degraded by sewage sludge: Effects on soil properties and erosion losses. Environ. Management, 31, 741-747.

Ros M., Klammer S., Knapp B., Aichberger K., and Insam H., 2006a. Long-term effects of compost amendment of soil on functional and structural diversity and microbial activity. Soil Use Management, 22, 209-218.

Ros M., Pascual J.A., Garcia C., Hernandez M.T., and Insam H., 2006b. Hydrolase activities, microbial biomass and bacterial community in a soil after long-term amendment with different composts. Soil Biol. Biochem., 38, 3443-3452.

Singh R.P. and Agrawal M., 2008. Potential benefis and risks of land application of sewage sludge. Waste Manag., 28, 347-358.

Suhadolc M., Schroll R., Hagn A., Dörfler U., Schloter M., and Lobnik F., 2010. Single application of sewage sludge Impact on the quality of an alluvial agricultural soil. Chemosphere, 81, 1536-1543.

Tejada M., Hernandez M.T., and Garcia C., 2006. Application of two organic amendments on soil restoration: Effects on the soil biological properties. J. Environ. Quality, 35, 1010-1017. 